\title{
Spatial distribution pattern of Mezilaurus itauba (Meins.) Taub. Ex mez. in a seasonal forest area of the southern Amazon, Brazil
}

\author{
Alexandre Ebert, \\ Reginaldo Brito Da Costa, \\ Gilvano Ebling Brondani
}

\begin{abstract}
Spatial analysis of forest tree distribution is a powerful tool to respond to basic ecological questions, and represent a useful support to strategies of genetic conservation and sustainable management practices of forest resources. Spatial analysis techniques combined with the use of Geographical Information Systems have been commonly applied to the study of stochastic processes in order to determine the existence of clusters to be related to microenviromental conditions and/or genetic factors. The present study focused on the distribution patterns of individuals of Mezilaurus itauba in a seasonal forest of the southern Amazon, with the aim of providing information about the spatial arrangement of these species at the juvenile and adult stages. Ripley's K function with radius of 10,20 and $30 \mathrm{~m}$ was used to describe spatial distribution patterns. The hypothesis of complete spatial randomness (CSR) of individuals was tested by constructing confidence envelopes for the Ripley's K function through Monte Carlo simulations using a Poisson homogeneous process. The results obtained suggest a general random distribution of individuals, though a tendency to clustering at close distances was detected for individuals classified as adults $(\mathrm{DBH}>50 \mathrm{~cm})$. Contrastingly, a completely randomized spatial pattern was found for juveniles trees $(\mathrm{DBH}<50 \mathrm{~cm})$. Our results provide a useful baseline for the development of sustainable management plans and conservation of Mezilaurus itauba, as well as for other economically-exploited, native tree species in the southern Amazon forest.
\end{abstract}

Keywords: Ripley's K Function, Spatial Distribution Patterns, Forest Management, Conservation of Biodiversity, Horizontal Structure in the Amazon forest (Laurance \& Peres 2006, Broadbent et al. 2008, Asner et al. 2009).

Mezilaurs itauba (Meins.) Taub. Ex Mez (Lauraceae - Aparício 2011) is an Amazon species distributed throughout South America, from the southern Amazon and northern Brazil to Colombia, Venezuela, Guyana, French Guiana and Ecuador. It is the fifth most exploited timber species in the region, due the excellent technical characteristics of the wood, and it is listed as threatened for extinction in the Amazon region by the International Union for Nature Conservation (IUCN 2009).

The shortage of studies on the structure and diversity of the Amazon forest represents a large deficiency in the ecological and management research (Durigan 2012,
College of Forestry Engineering, Federal University of Mato Grosso, Cuiabá (Brazil)

@ Alexandre Ebert (ebertfloresta@yahoo.com.br)

Received: Aug 15, 2014 - Final revision: Aug 04, 2015 - Final Acceptance: Jan 22, 2016

Citation: Ebert A, Brito Da Costa R, Brondani GE (2015). Spatial distribution pattern of Mezilaurus itauba (Meins.) Taub. Ex mez. in a seasonal forest area of the southern Amazon, Brazil. iForest 9: 497-502. - doi: 10.3832/ifor1427-008 [online 2016-01-25]

Communicated by: Chris Eastaugh
FAO 2012). In this context, the spatial distribution of tree species is a key issue for better understanding how a species uses the available resources, its successful establishment and reproduction (Condit et al. 2000). The horizontal distribution of a species in the forest is affected by the density of seed sources, seed dispersion and post-dispersion processes. In turn, seed source density is affected by the density of potentially reproductive individuals and by the reproductive system of the species (Bleher et al. 2002), with important implications concerning its genetic diversity. Moreover, spatial distribution patterns are often related to interactions between biotic and abiotic factors that control the dynamics of the ecological processes within a population (Capretz 2004).

Timber exploitation can alter the spatial distribution of individuals scattered over a given area, affecting the reproduction, competition, survival ability and predation mechanisms of the populations. For example, reproductive processes such as pollen flow may be affected by significant alterations in the dynamics of clearings originated from harvesting (Cunha 2003). Furthermore, logging may significantly reduce tree density and consequently increase the distance between individual trees, leading to alterations in the pollen flow between individuals (Murawski \& Hamrick 1991, Degen 


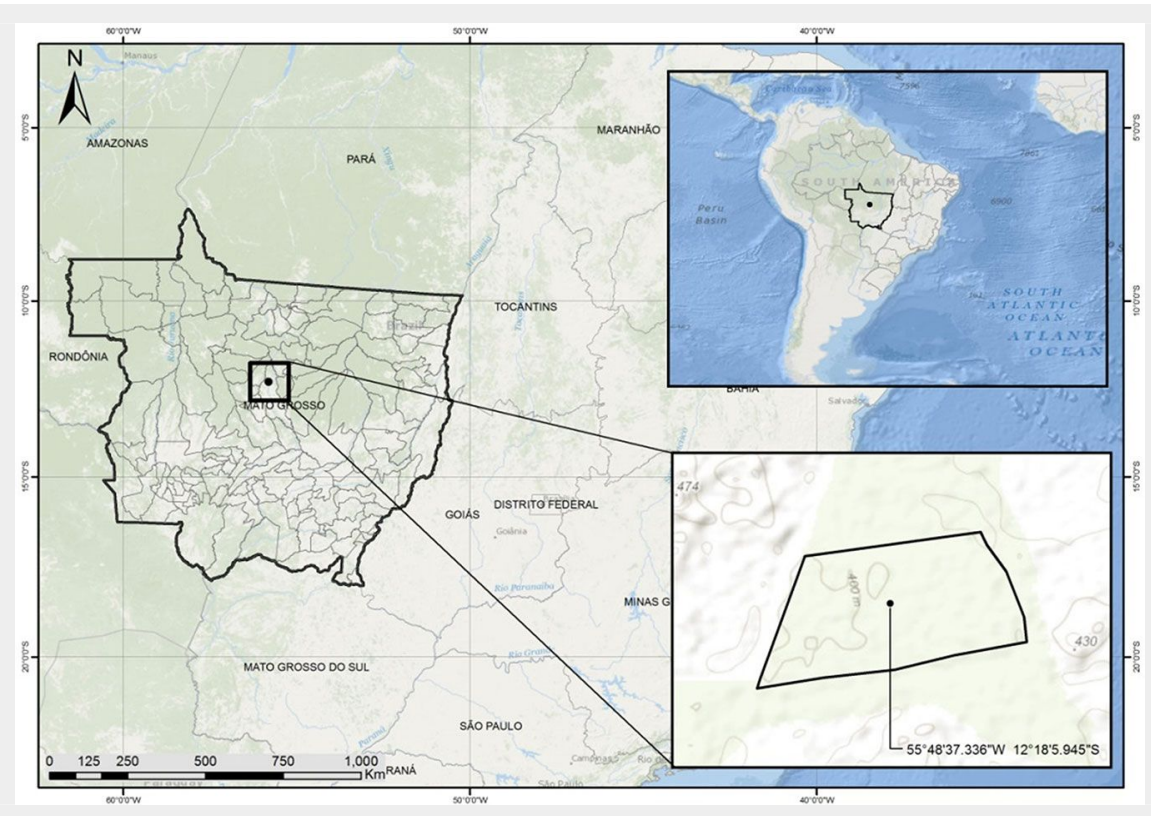

Fig. 1 - Map of the study area.

\& Roubik 2004).

Basically, the distribution of individual trees in the forest may show three theoretical patterns: uniform, random and aggregate (Begon et al. 2006, Silva et al. 2012). Aggregated patterns are commonly observed when a positive or attractive association among individuals takes place, leading to the positive autocorrelation values at short distances (Perry et al. 2002). On the contrary, uniform or regular patterns are characterized by negative autocorrelation with repulsive relationships among individuals. In general, species present clustered patterns when considered at larger scales, mainly due to the contiguity of suitable habitats (Lieberman \& Lieberman 1994, Dixon 2002). However, populations of species may show different combinations of spatial patterns, depending of the scale considered. Indeed, some populations present clustered patterns at large scales and random at small scales, which can be related to the aforementioned synecological aspects, such as pollination, seed and propagules dispersal, the reproductive systems, etc.

Ripley's K function (Ripley 1977) is a descriptive statistics of spatial patterns widely used in the analysis of spatial patterns of forests. It is based on the computation of the expected number of points within a circle of radius ( $r$ ) centered at an arbitrary reference point, divided by the intensity $(\lambda)$ of the pattern (Capretz 2004). This method evaluates how the spatial patterns of any event at different scales simultaneously occupies a space (Capretz 2004), thus the degree of interaction between trees within a population or community can be evaluated (Penttinen et al. 1992, Druck et al. 2004, Silva et al. 2012).

The concept of Complete Spatial Randomness (CSR) is crucial for the quantitative description of any spatial pattern. An event $X$ is a partial realization of a homogeneous Poisson process, which involves a single parameter, $\lambda$ (intensity) or the average number of events per unit area. According to Durigan (2012), the actual number of events ( $n)$ in $X$ is an observation of a Poisson distribution with a mean intensity $\lambda(X)$. Moreover, the same author reported that the hypothesis to be tested in the bivariate analysis is not CSR, but the Complete Spatial Independence (CSI) of processes, shifting the focus from "aggregate vs. regularity" to "attraction vs. repulsion" among processes.

The present study aimed at identifying the spatial patterns of tree distribution in a population of Mezilaurus itauba (Meins.) Taub. Ex mez. in a seasonal forest of the southern Amazon (Brazil). The main goal was to understand how the reproduction and establishment of such species can be influenced by timber exploitation under the current forest management regime in the southern Amazon region (Condit et al. 2000, Dalmaso et al. 2013), thus contributing to sustainable forest management and conservation of genetic diversity of the species (Capretz 2004, Law et al. 2009).

\section{Material and methods}

\section{Study area}

The study was carried out in an area of tropical rainforest located in the north of the Mato Grosso state, Brazil $\left(12^{\circ} 18^{\prime} \mathrm{S}, 55^{\circ}\right.$ $48^{\prime} \mathrm{W}$ - Fig. 1). A fragment of forest typologically classified as semi-deciduous seasonal forest was selected in the southern Amazon plane, predominantly composed by evergreen or semi-deciduous trees and influenced by both the super humid climate of the Amazon and the humid tropical central plateau (IBGE 2012). Soils were dystrophic red-yellow latosol, i.e., hydromorphic mineral soils with latossolic B horizon, characterized by red and red-yellow colors due to high levels of $\mathrm{Fe}_{2} \mathrm{O}_{3}$. The study area is set in a typical agricultural region, with scattered fragments of the Amazon forest included in reserves established by law in order to allow the dynamic conservation of the forest ecosystem resources.

A preliminary mapping of the study site was made using the software $\operatorname{ArcGIS}^{\circledast} 10.0$ based on orbital images obtained by remote sensing. A total area of 185 ha was delineated in the forest interior with a minimum distance of $100 \mathrm{~m}$ from stream margins, swampy and infrastructure areas, to avoid any edge effect or interference with the frequency and density of the studied species. Eighteen transects of $50 \mathrm{~m}$ were established over the area, and all the stems of Mezilaurus itauba with a minimum diameter at breast height (DBH) of $30 \mathrm{~cm}$ were identified along the transects. Tree positioning was taken using a hand-held GPS. For each tree the DBH was measured, total and commercial height estimated using an electronic clinometer, and the phytosanitary state of the stem recorded. All the data were collected simultaneously. Species identification was carried out in situ by comparing specimens collected in the field with the specimens deposited in the Central Herbarium of the Federal University of Mato Grosso (Brazil).

During tree inventory, individuals were classified into two groups according to their maturity stage: juvenile trees $(<50 \mathrm{~cm}$ $\mathrm{DBH})$ and adult trees (>50 cm DBH). Such threshold was chosen based on the current legislation of Brazil, which allows only trees with $>50 \mathrm{~cm}$ to be harvested.

Mathematical and statistical analyses were carried out using electronic worksheets and the statistical software package $\mathrm{R}$ version 3.0.1. The $\mathrm{K}$ function proposed by Ripley (Haase 1995) was tested against the null hypothesis of complete spatial randomness (CSR) based on diagrams where the distances tested between events are represented in the abscissa, and the values of the $\mathrm{K}$ function in the ordinate. Such graphical representation facilitated the visualization of deviations from the null hypothesis. Data were processed both pooled together and independently for juveniles $(\mathrm{DBH}<50 \mathrm{~cm})$ and adult $(\mathrm{DBH}>50 \mathrm{~cm})$ trees. Circles with radius of 10,20 and $30 \mathrm{~m}$ were used in the analyses.

Confidence envelopes for Ripley's K values were constructed through Monte Carlo simulations, whose number varied according to the required precision. According to Cunha (2003), 19 simulations are required to achieve 5\% confidence envelopes, and 99 simulation for $1 \%$ confidence envelopes. When the number of trees was not too large, 1000 simulations were carried out to achieve an acceptable level of probability.

The complete spatial randomness (CSR) scenario was defined by performing 1000 Monte Carlo simulations with $\alpha=0.01$ using a Poisson homogeneous process. Envelo- 
pes with maximum and minimum values were then generated and confidence limits obtained. Values of the $\mathrm{K}$ function at different distances were plotted along with confidence intervals obtained under the null hypothesis of complete spatial randomness. Values falling within the envelope were not statistically different from their expectation based on CSR. Values above the superior line of the envelope indicated a grouped or aggregate spatial distribution of individuals, while values below the inferior line indicated a spatially uniform (regular) distribution of individuals.

\section{Results and discussion}

Overall, 229 individuals of Mezilaurus itauba were detected across the study area, resulting in an absolute density of 1.23 individuals ha $^{-1}$. At least one individual of the studied species was detected along each transect. The $x$ and $y$ coordinates were represented in a Cartesian orthogonal plane to display the spatial localization of trees (Fig. 2).

The total abundance of individuals was 156 for adult trees $(\mathrm{DBH}>50 \mathrm{~cm})$ and 73 for juveniles (DBH $<50 \mathrm{~cm}$ ). This distribution of individuals within diametric classes was atypical when compared to other tree species. Indeed, in tropical forests such distribution usually shows an "inverted J" shape, with a lower number of trees at intermediate $\mathrm{DBH}$. Costa \& Mantovani (1995) described the frequency distribution of size classes to follow an inverted $J$ curve in various species, reporting a large number of individuals in the lower classes gradually decreasing as size increased. Similar results were presented by Severiano et al. (2011) and Dalmaso et al. (2013). Péllico Neto et al. (2007) reported that the diametric structure of Ocotea odorifera in fragmented forests also follows an inverted J curve, with a high frequency in the smallsize classes gradually decreasing with increasing the tree size.

To verify the spatial distribution of adult trees in the study area, a map was generated including only individuals with DBH > $50 \mathrm{~cm}$ and using the same radius distance (Fig. 3a). Scattered groups of trees were detected over the whole area, though a grouping tendency was observed particularly in the lower section of the map, with 10 to 20 individuals per group. Due to their close distance, these individuals might be subject of preferential mating by biotic and abiotic pollination. In contrast, the upper part of Fig. 3a suggests spatial randomness of individuals with more scattered trees fewer groups. However, the fairly close distance among trees still allows potential genetic exchanges among these individuals.

When the spatial distribution of juvenile trees was analyzed using the same distance radius, a reduction in the number of events was observed as well as a random distribution of individual trees (Fig. 3C).

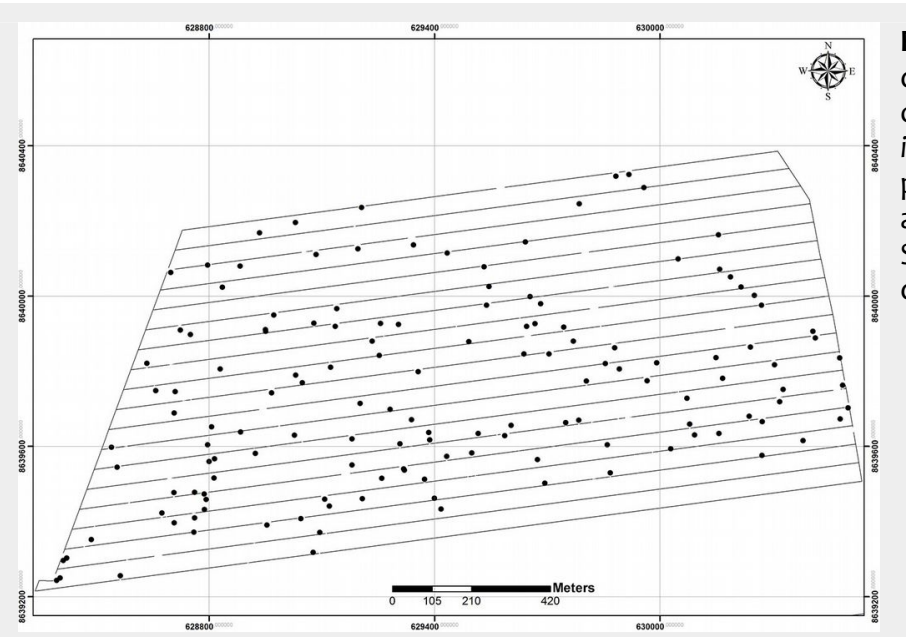

Fig. 2 - Pinpoint distribution map of Mezilaurus

itauba trees sampled in the study area (reference: SIRGAS 2000 map datum).

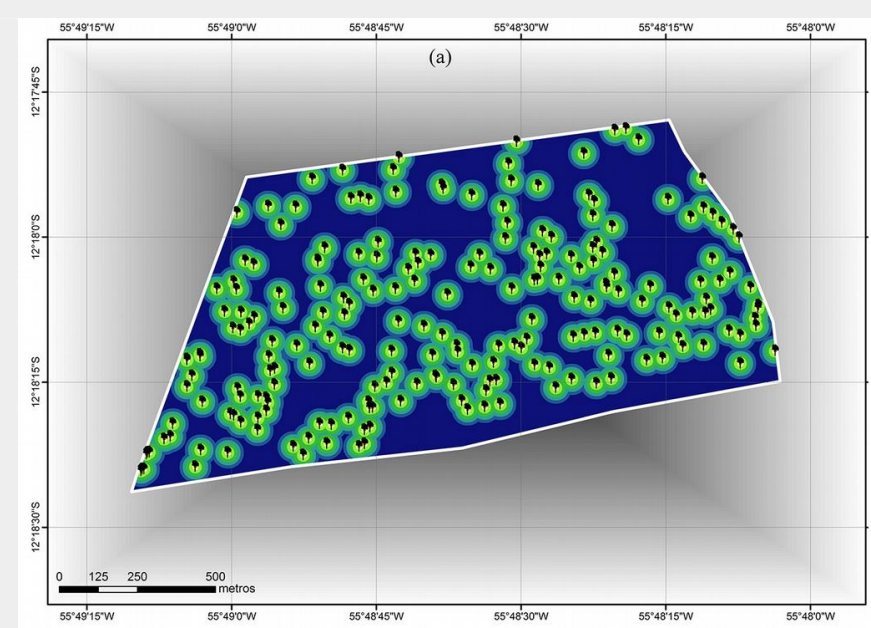

Fig. 3 - Spatial point distribution of inventoried Mezilaurus itauba trees: (a) general with all adult and juvenile trees; (b) adult trees only; (c) juvenile trees only. A distance radius of 10,20 and $30 \mathrm{~m}$ was used.
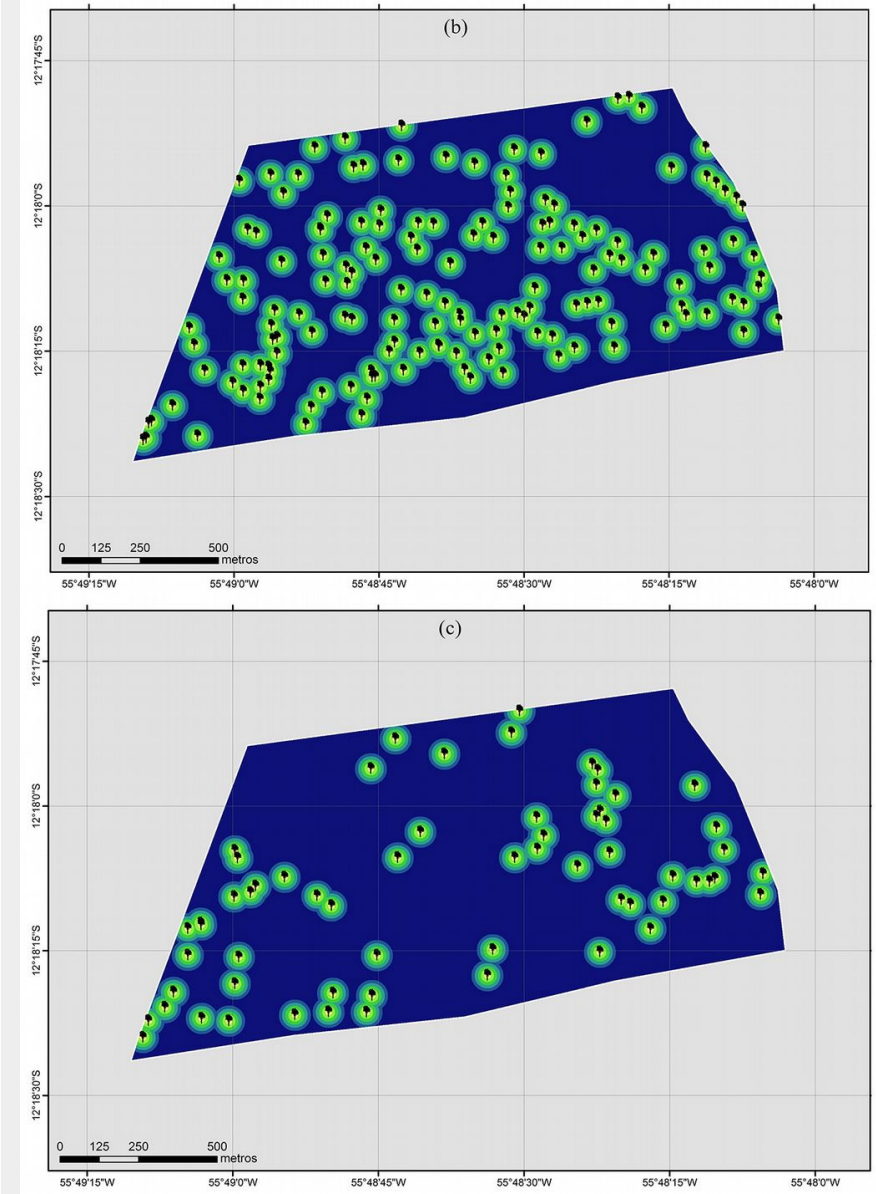
(a)

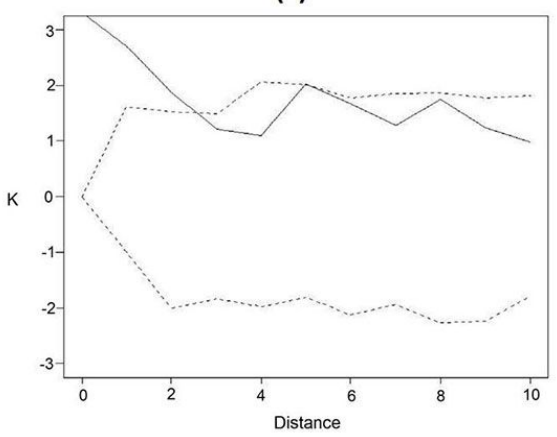

(d)

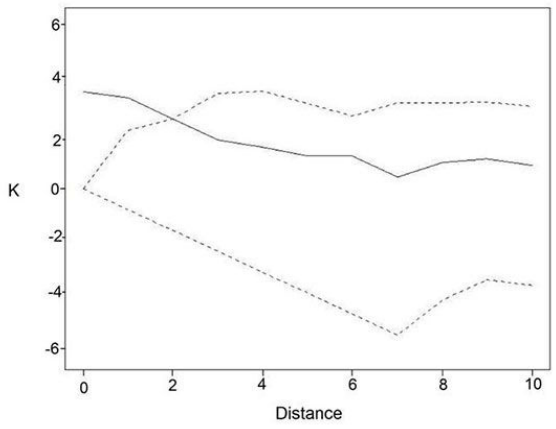

(g)

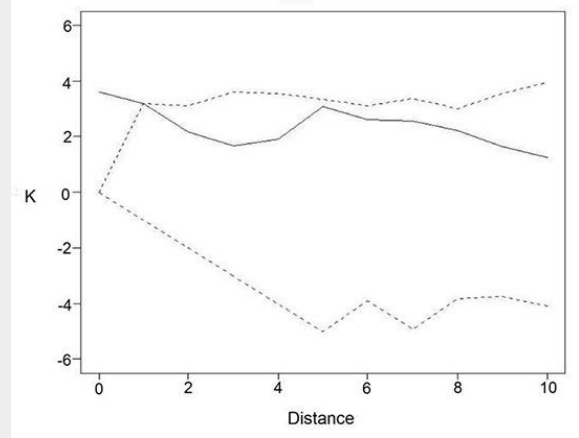

(b)

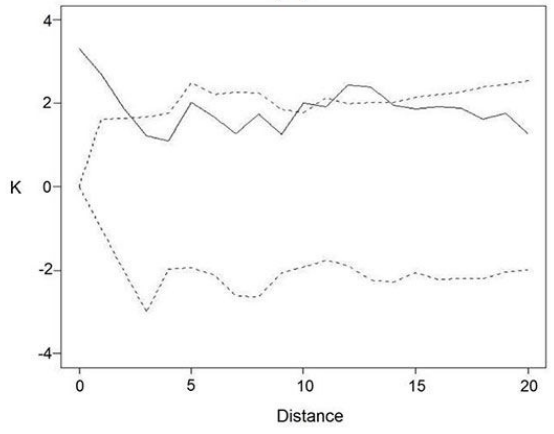

(e)

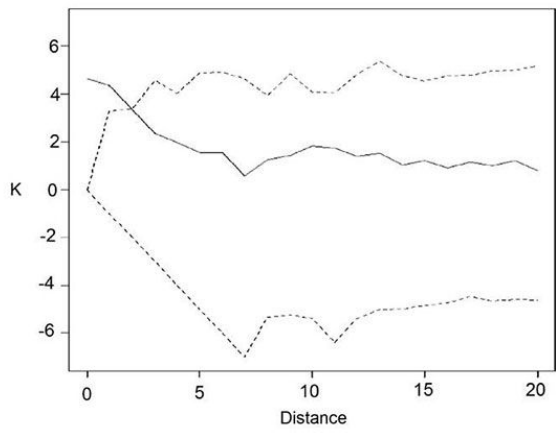

(h)

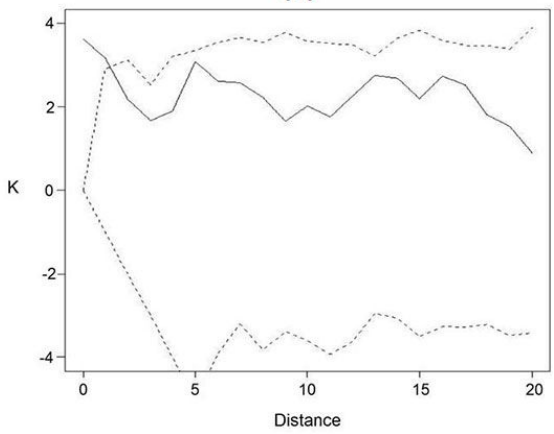

(c)

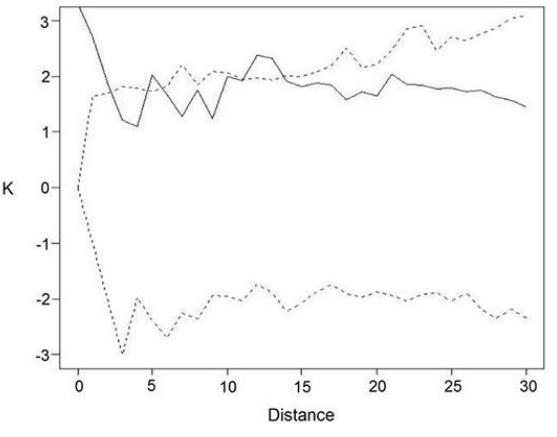

(f)

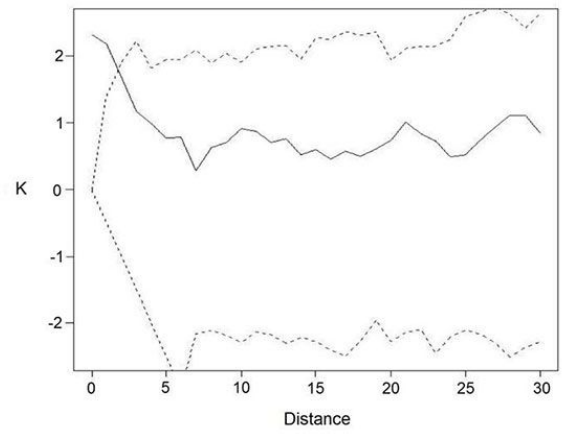

(i)

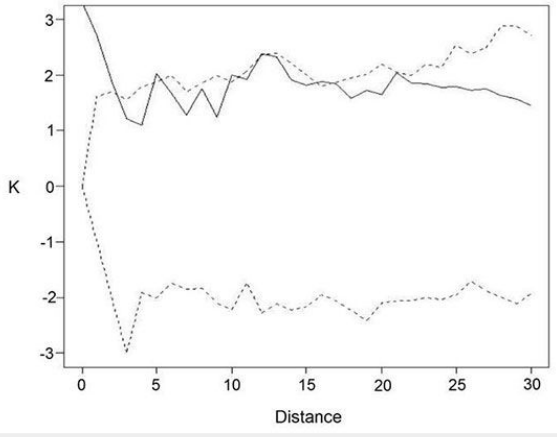

Fig. 4 - Analysis of the spatial distribution pattern through the Ripley's $K$ function for different distances ( $L$ ) of juvenile and adult Mezilaurus itauba individuals; (a, d, g): $L=10 \mathrm{~m}$; (b, e, h): L=20 m; (c, f, i): L=30 m. (a, b, c): all inventoried individuals; (d, e, f): adult inventoried individuals; $(\mathrm{g}, \mathrm{h}, \mathrm{l})$ : the juvenile inventoried individuals. The dotted line represents the confidence envelope (\%) for 1000 Monte Carlo simulations, whereas dashed lines are 0.025 and 0.0975 quantiles of K estimated from 1000 simulations.

Even in this case, juvenile trees were observed in all transects.

\section{Distribution pattern by Ripley's K function}

Overall, the starting hypothesis of complete spatial randomness of Mezilaurus itauba in the study area was confirmed based on our analysis. However, the Ripley's $\mathrm{K}$ function at short distances showed values exceeding their expectations based on the random distribution, indicating a weak though significant aggregation of the sampled trees. Similar results were obtained when the analysis was carried out independently on adults and juvenile trees, with $\mathrm{K}$ values calculated for distances of 5-13 m were exceeding their random expectations. For larger distances, $\mathrm{K}$ values were always included within the envelopes based on the CSI hypothesis, indicating no significant differences from the random distribution of trees.
Using a $10 \mathrm{~m}$-distance radius, a random distribution pattern was detected, with all points falling within the confidence envelope (Fig. 4a, Fig. 4d, Fig. 4g). However, a significant spatial clustering (as inferred from the $\mathrm{K}$ line above the upper $97.5 \%$ quantile) was detected for distances up to 3 meters (Fig. 4a), 2 meters (Fig. 4b) and 3 meters (Fig. 4g), indicating a tendency to aggregation. Similar patterns were observed when a radius of 20 or $30 \mathrm{~m}$ was set in the analysis, confirming the occurrence of small groups of 10 to 15 individuals of Mezilaurus itauba close to each other with a likely co-ancestral origin (Fig. 4).

In general, a random distribution of juvenile individuals was detected in this study (Fig. 4a, Fig. 4b, Fig. 4c), regardless the radius used in the analysis (10, 20 or $30 \mathrm{~m})$. The density of juvenile individuals was lower then that of adult trees, which could be related to factors like pollination and/or seed dispersion. It could be hypothesized that CSR of juveniles might be due to interand intra-specific competition.

In the univariate analysis of adult trees a random spatial distribution was observed, but with a tendency to cluster at a distance up to $20 \mathrm{~m}$ (Fig. 4b). The density observed for adult trees was higher when compared to young individuals of Mezilaurus itauba. This behavior was observed in studies on nost tree species in the Amazon region. The lower density of young trees has been interpreted as due to intra- and interspecific competition, and the reproductive system of the species, as well as to soil and microclimatic conditions.

The spatial distribution of Mezilaurus itauba trees detected in this study may reflect both autoecological aspects (e.g., seed dispersal) and interaction with the environment (e.g., availability of resources such as light and essential nutrients). Odum (1983) reported that, in general, regular or random distribution of individuals may be 
related to either competition on limited resources or direct antagonism (e.g., allelopathy). Gourlet-Fleury et al. (2005) reported the effects of the removal of larger individuals in populations of timber trees, highlighting the importance of reproductive ecology in determining the distribution and dynamics of the populations.

\section{Conclusions}

In this study, the main spatial pattern of the population of Mezilaurus itauba in the southern Amazon was random, though a tendency to aggregation at very close distances was detected. Perry \& Dixon (2002) reported that biological factors such as vegetative growth, dispersal or inter- and intra-specific interactions, were responsible for the aggregate patterns found for some species. Indeed, the spatial arrangement reflects the structure of populations, which in turn affects their renewal by the adult reproductive trees.

Juvenile trees of Mezilaurus itauba in this study presented a pattern of complete spatial randomness. The observed distance between adult and juvenile trees within the analyzed population is consistent with a substantial pollen exchange, thereby allowing a considerable gene flow and a long-term maintenance of the observed genetic structure.

The distribution patterns analyzed by the Ripley's K function may provide a baseline for the exploration of other native species in the southern Amazon, as well as for forest management programs aimed at determining the gene flow rates and the reproductive system of economically exploited species. Spatial distribution of harvested species provide the essential information needed in the development of sustainable management plans and conservation of natural ecosystems programs.

\section{Acknowledgements}

This study was financially and supported by "Coordenação de Aperfeiçoamento de Pessoal de Nível Superior" (CAPES) and "Conselho Nacional de Desenvolvimento Científico e Tecnológico" (CNPq), Brazil.

\section{References}

Aparício WCS (2011). Estrutura da vegetação em diferentes ambientes na resex do Rio Cajari: interações solo-floresta e relações com a produção de castanha [Structure of the vegetation in different environments in the Resex Rio Cajari: forest-soil interaction and relationships with chestnut production]. Ph.D. thesis, Universidade Federal de Pernambuco, Recife, PE, Brazil, pp. 150. [in Portuguese]

Asner GP, Rudel TK, AideTM, Defries R, Emerson $R$ (2009). A contemporary assessment of change in humid tropical forests. Conservation Biology 23: 1386-1395. - doi: 10.1111/j.1523-1739.2009. 01333.x

Begon M, Townsend C. R, Harper JL (2006). Ecology: from individuals to ecosystems ( $\left.4^{\text {th }} \mathrm{edn}\right)$. Blackwell, Oxford, UK, pp. 752.

Bleher B, Oberrath R, Böhning-Gaese K (2002).
Seed dispersal, breeding system, tree density and the spatial patter of trees - a simulation approach. Basic and Applied Ecology 3: 115-123. doi: 10.1078/1439-1791-00088

Broadbent E, Asner GP, Keller M, Knap D, Oliveira P, Silva J (2008). Forest fragmentation and edge effects from deforestation and selective logging in the Brazilian Amazon. Biological Conservation 141 (7): 1745-1757. - doi: 10.1016/j. biocon.2008.04.024

Capretz RL (2004). Análise dos padrões espaciais de árvores em quatro formações florestais do estado de São Paulo, através de análises de segunda ordem, como a função K de Ripley [Spatial pattern analysis of trees of four forest communities in southeastern Brazil using the Ripley's K function]. Dissertação de Mestrado, Escola Superior de Agricultura Luiz de Queiroz, Piracicaba, SP, Brazil, pp. 79. [in Portuguese] CDB (2010). Forest Biodiversity - Earth's living treasure. Secretariat of the Convention on Biological Diversity, Montreal, Canada, pp. 48.

Condit R, Ashton P, Baker P (2000). Spatial patterns in the distribution of tropical tree species. Science 288 (5470): 1414-1418. - doi: 10.1126/sci ence.288.5470.1414

Costa LGS, Mantovani W (1995). Flora arbustivoarbórea de trecho de mata mesófila semidecídua, na estação ecológica de Ibicatu, Piracicaba, SP, Brazil [Shrub and tree flora of the semideciduous forest section in the ecological station of Ibicatu, Piracicaba, SP, Brazil]. Hoehnea 22: 47-59. [in Portuguese]

Cunha US (2003). Análise da estrutura espacial horizontal de uma floresta de terra firme da Amazônia [Analysis of horizontal spatial structure of an Amazonian terra firme forest]. Ph.D. Thesis, Universidade Federal do Paraná, Curitiba, PR, Brazil, pp. 179. [in Portuguese]

Dalmaso CA, Inoue MT, Oliveira Filho PC, Marcelino VR (2013). Padrões espaciais na regeneração de Ocotea odorifera na floresta nacional de Irati, PR [Spatial patterns of Ocotea odorifera regeneration in National Forest, Irati, PR]. Revista Floresta 43: 301-312. [in Portuguese] doi: 10.5380/rf.v43i2.28904

Davidson EA, Araujo AC, Artaxo P, Balch JK, Brown IF, Bustamante MMC, Coe MT, Defries RS, Keller M, Longo M, Munger JW, Schroeder W, Soares Filho BS, Souza CMJ, Wopsy SC (2012). The amazon basin in transition. Nature 481: 321-328. - doi: 10.1038/nature10717

Degen B, Roubik DW (2004). Effects of animal pollination on pollen dispersal, selfing, and effective population size of tropical trees: a simulation study. Biotropica 36: 165-179. - doi: 10.1111/j.1744-7429.2004.tboo309.x

Dixon PM (2002). Nearest-neighbor contingency table analysis of spatial segregation for several species. Ecoscience 9 (2): 142-151. [online] URL: http://www.jstor.org/stable/42901478

Druck S, Carvalho MS, Câmara G, Monteiro AMV (2004). Análise espacial de dados geográficos [Spatial analysis of geographic data]. EMBRAPA, Brasilia, DF, Brazil, pp. 190. [in Portuguese] Durigan G (2012). Estrutura e diversidade de comunidades florestais [Structure and diversity of forest communities]. In: "Ecologia de Florestas Tropicais do Brasil (2 $2^{\text {nd }}$ edn)" (Martins SV ed). Editora UFV, Viçosa, MG, Brazil, pp. 294325. [in Portuguese]
FAO (2012). Forest management and climate change: a literature review. Food and Agriculture Organization of the United Nations, Rome, Italy, pp. 46.

Gourlet-Fleury S, Blanc L, Picard N, Sist P, Dick J, Nasi R, Swaine MD, Forni E (2005). Grouping species for predicting mixed tropical forest dynamics: looking for a strategy. Annual of Forest Science 62 (8): 785-796. - doi: 10.1051/forest :2005084

Haase P (1995). Spatial pattern analysis in ecology based on Ripley's K-function: introduction and methods of edge correction. Journal of Vegetation Science 6: 575-582. - doi: 10.2307/3236 356

IBGE (2012). Manual técnico da vegetação brasileira: sistema fitogeográfico, inventário das formações florestais e campestres, técnicas e manejo de coleções botânicas, procedimentos para mapeamentos [Technical manual of the Brazilian vegetation: phytogeographic system, inventory of forest and grasslands, technical and management of botanical collections, procedures for mapping] (2nd edn). IBGE - Instituto Brasileiro de Geografia e Estatística, Rio de Janeiro, RJ, Brazil, pp. 275.

IUCN (2009). IUCN red list of threatened species (version 2009.2). International Union for Conservation of Nature, Web Site. [online] URL: http://www.iucnredlist.org

Laurance WF, Peres CA (2006). Emerging threats to tropical forests. University of Chicago Press, Chicago, IL, USA, pp. 563. [online] URL: http:// books.google.com/books?id=rVPTbEycT-oC

Law R, Illian J, Burslem DFRP, Gratzer G, Gunatilleke CVS, Gunatillekel (2009). Ecological information from spatial patterns of plants: insights from point process theory. Journal of Ecology 97: 616-628. - doi: 10.1111/j.1365-2745.20 09.01510.x

Lieberman M, Lieberman D (1994). Patterns of density and dispersion of forest trees. In: “La Selva: Ecology and Natural History of a Neotropical Rain Forest" (McDade L, Bawa KS, Hartshorn GS, Hespenheide $\mathrm{H}$ eds). University of Chicago, Chicago, IL, USA, pp. 106-119. [online] URL: http://books.google.com/books? id=FLqa_WpbROoC

Murawski DA, Hamrick JL (1991). The effect of the density of flowering individuals on the mating systems of nine tropical tree species. Heredity 67: 167-174. - doi: 10.1038/hdy.1991.76

Myers N, Mittermeier RA, Mittermeier CG, Fonseca GAB, Kent J (2000). Biodiversity hotspots for conservation priorities. Nature 403: 853858. - doi: $10.1038 / 35002501$

Odum HT (1983). Systems ecology. Wiley, New York, USA, pp. 644.

Penttinen A, Stoyan D, Henttonen HM (1992). Marked point processes in forest statistics. Forest Science 38: 806-824. [online] URL: http:// www.ingentaconnect.com/content/saf/fs/1992/ $00000038 / 00000004 / a r t 00007$

Perry JN, Dixon PM (2002). A new method to measure spatial association for ecological count data. Ecoscience 9 (2): 133-141.

Perry JN, Liebhold AM, Rosenberg MS, Dungan J, Miriti M, Jakomulska A, Citron-Pousty $S$ (2002). Illustrations and guidelines for selecting statistical methods for quantifying spatial pattern in ecological data. Ecography 25 (5): 578- 
600. - doi: 10.1034/j.1600-0587.2002.250507.x Péllico Neto S, Fabroswski FJ, Weber SH (2007). Análise da estrutura diamétrica do sassafrás (Ocotea odorifera (Vell. ) Rohwer) em fragmentos florestais no município de Fazenda Rio Grande. Paraná, PR, Brazil [Analysis of diameter structure of sassafras (Ocotea odorifera (Vell.) Rohwer) in forest fragments in the municipality of Fazenda Rio Grande. Paraná, Paraná, Brazil]. Ambiência 3: 167-181. [in Portuguese]

Ripley BD (1977). Modelling spatial patterns. Journal of the Royal Statistical Society, Series B 39: 172-192. [online] URL: http://www.jstor.org/ stable/2984796

Rocha VM, Correia FWS, Fialho ES (2012). A
Amazônia frente às mudanças no uso da terra e do clima global e a importância das áreas protegidas na mitigação dos impactos: um estudo de modelagem numérica da atmosfera [The Amazon in the face of land cover and global climate changes and the importance of protected areas in mitigation of impacts: a study of numerical modeling of the atmosphere]. Acta Geográfica pp. 31-48. [in Portuguese]

Severiano CE, Aparício PS, Aparício WCD, Sota ED, Guedes MC, Oliveira LPS (2011). Distribuição diamétrica, espacial, características ecológicas e silviculturais de Mezilaurus itauba (Meisn.) Taub. ExMez, na floresta do estado do Amapá (Flota/AP), Brasil [Diameter and spatial distribu- tion, ecological and silvicultural characteristics of Mezilaurus Itauba (Meisn.) Taub. ExMez in the Amapá State Forest (Flota / AP), Brazil]. In: Proceedings of the "V Simpósio Latino Americano Sobre Manejo Floretal". Santa Maria (RS, Brazil) 22-24 Sep 2015, pp. 526-533. [online] URL: http://www.alice.cnptia.embrapa.br/hand le/doc/916558

Silva KE, Martins SB, Santos NT, Carlos A, Ribeiro AS (2012). Padrões Espaciais de Espécies Arbóreas Tropicais [Spatial patterns of tropical tree species]. In: "Ecologia de Florestas Tropicais do Brasil” (Martins SV ed). Editora UFV, Viçosa, MG, Brazil 1: 326-352. [in Portuguese] 